\title{
Leadership in the mental health service: what role for doctors?
}

\author{
John Reed, CB
}

Policy and proctice in the care of people with a mentel Wheis has been changing radicelly for many years. This aiticlo drows attention to the important rolo doctors can play in infiuencing the dovelopment of central pollcies and to the need for kaderehtp, including leaderehlp by doctors, in doveloping a montal hoctith senvice for the noxd century.

As long ago as 1959 the Chief Medical Officer's annual report (Ministry of Health, 1960) recorded that "the wind of change had been blowing through psychiatry." A prominent feature of the change according to the CMO was "the realisation that the restraints and restrictions used in mental hospitals in the past are now unnecessary and that if the psychological atmosphere of the hospital is appropriate to the needs of the patients then remarkable improvement occurs and the deteriorated, hostlle, aggresstve, dirty, frightened, distraught patients largely disappear".

Developments in central policy are often reflections of a climate of opinion created by, among other things, improvements or deteriorations in clinical practice. For instance, even while the mental hospital system was growing (itself a response to the bad practice of the private 'mad houses' of the late 18th and early 19th century) moves away from an institution-based service were occurring. The first domiciliary crisis intervention service for mentally ill people opened at Barnhill Hospital, Glasgow, in 1880 and an out-patient clinic at St Thomas' Hospital in London in 1889. Central policy responded in, for instance, the Board of Control proposal in 1918 (Board of Control, 1919) for "sections at general hospitals for the early diagnosis and treatment of incipient

Based on a lecture given at the Royal College of Psychiatrists Annual General Meeting. July 1994. cases, Including organised study and research where the hospital is attached to a medical school".

Another local improvement in service which became part of the central policy was the move towards care in less restrictive conditions (Lancet 1954). There was at first no centrally drtven policy of unlocking doors in hospitals. As Ramon, using Littlemore Hospital which adopted an open door policy in 1992 (Goode, 1930, 1954; Lancet, 1954) as an example, points out, "the demand did not come from the outside (1.e. the government, the general public, politiclans) or from the inside (the inpatient population or other professions.)" She concluded that, "It was engineered by psychiatrists inside the hospitals who had to struggle with the rest of the staff and often with the local community too to get it going and to let the doors stay open" (Ramon, 1985).

Improved treatments making less use of inpatient care and changed social attitudes led from 1954 to a fall in the number of patients resident in hospital and central policy again responded to these clinical developments. In 1957 the report of the Royal Commission under Lord Percy pointed the way to a breaking down of barriers between mentally III or mentally handicapped people and the general population. And Ministers in England set out new policies for the mental health services; first in 1961 in Enoch Powell's, the then Minister, famous Water Towers' speech (Powell, 1961) and subsequently in the 1975 White Paper Better Services for the Mentally III (Department of Health and Social Security, 1975). Policy statements that still, in general, hold good.

It is not unreasonable to conclude that, for the future as for the past, improvements in treatment and care in the mental health service will play a large part in determining the future direction of national policy. And improvements in practice depend on the skdlls and commitment of those working in the 
service and particularly of its consultants both present and future. As a Minister for Health said some years ago:

"We may be sure that the progress of medical thought and method will still be well ahead of our Departmental) practice." (Powell, 1961).

The doctors who developed and drove through such important changes in the mental health service showed vision and leadership. Both are needed still from doctors to ensure a mental health service fit for the 2lst century.

\section{Criticisms of lack of leadership by doctors}

But for many years reports of committees of enquiry from that into Ely Hospital in 1969 to that on South Devon in 1994, have criticized doctors for lack of leadership (Department of Health and Social Security, 1969; Department of Social Services, 1971; Department of Health and Social Security 1972; Department of Health and Social Services, 1974; Department of Health (1992a).

\section{In 1969}

"...he (the consultant) has had an insufficient apprectation of his necessary role as a spur to improvement... It was his duty to gtve the necessary stimulus and encouragement to his medical colleagues."

\section{And in 1994}

"Professional leadership for both medical and nursing staff was mentioned, by almost all... as being serfously lacking in the mental health services. The dearth of identiflable leaders is a theme running through previous reports about the service." (South Devon Healthcare, 1994).

The earlier serles of reports was summed up simply

"Though of course there are problems of resources, the underlying common feature about many of the enquiry reports seems to be low stafi morale... (and)...complaints about lack of effective leadership... (Secretary of State for Social Services, 1977).

\section{Leadership and management}

Much is currently heard about 'management' but very little of 'leadership'. What is the difference between the two? Leadership has been defined as "discovering the route ahead and encouraging and inspiring others to follow. A good leader should both show the way and make others enthusiastic about following it." While Management is a set of techniques and approaches which make it possible for goals to be achieved by the "discipline of objectives, targets and reviews". Both leadership and management have important but differing roles.

\section{Leadership in the NFS}

It has rightly been said that "in difficult times, people need leadership as well as management. This is true in the NHS today, and in the foreseeable future. Yet 'leadership' is a word many in the NHS are chary of using" (Stewart, 1989). 'Uncomfortable' is a good word to describe how many in the mental health services and elsewhere feel about leadership. Maslow commented on this discomfort in 1965.

What I smell here is again some of the democratic dogma and plety in which all people are equal and in which the conception of a factually strong person or natural leader - is bypassed because it makes everyone uncomfortable and because it seems to contradict the democratic philosophy." (Maslow, 1965).

That this remained true 20 years later is clear from the comment of another psychologist summing up a conference on leadership in 1986, "I must admit that I have certain reservations about every leader, great or small. I sniff at him from afar, and quickly move away" (Moscovici, 1986).

Leadership can, like anything else, be incompetent or misused (Dixon, 1976/1994) but does it deserve to be as closely linked with the name of Adolf Hitler as it was in a recent scientific symposium on leadership including leadership in science? Yet the same symposium concluded that "Leadership is ... unavoidable".

\section{Leadership in the mental health service}

A recent paper on the work of consultant psychiatrists made no mention of the need to act as a leader either operationally or strategically though other publications have centred on an insistence that the consultant must lead the multidisciplinary team (Sims, 1989; Sims \& Sims, 1993; Royal College of Psychiatrists, 1992). The Royal College of Psychiatrists' paper The Mental Health of the 
Nation says that consultants should lead the multidisciplinary team because of "their postgraduate training... spanning biological and social treatments" and recognises that a leader needs to take responsibility for the effective running of the team. But The Mental Health of the Nation assumes that the necessary leadership skdlls are either innate or are already taught during training. Surveys of trainees suggest that while management issues are usually addressed in training leadership is rarely discussed.

\section{Stratepic leadership}

The mental health service continues to undergo masstve changes in its move from an institution-based service to a locally based one and change demands leadership. Are psychiatrists paying sufficient attention to this strategic element in the role of leaders? Or are doctors, as Smith (1992/93) suggests, really only happy in their one to one relationships with patients, in which case they should leave both operational and strategic leadership to others; a highly unwelcome scenario.

\section{Operational leaderahip in muitidisciplinary teams}

Working in a team is a central feature of psychiatric practice and without clear leadership and effective communications teams do not work well and often fall to achieve what they set out to do. They may not even agree on what they are trying to do. The poor case-mix of community psychiatric nurses with an over-emphasis on minor morbidity is but one example (White, 1991) of fallure to agree clear objectives. Without effective communication disasters such as the case of Christopher Clunis will be more likely to occur (Ritchie et al, 1994).

In short, both strateglc and operational leadership are necessary in the mental health service.

\section{The characteriatics of leadership}

Not all professions are as wary of leadership as doctors. Others deal openly with issues of leadership and have tried to define what makes a person a good leader. Xenophon's speech (translation, 1949) to the Greek troops on assuming command after the battle of
Cunaxa In 401 BC sets out plainly the necessary characteristics of a leader including willingness to take decisions and to be the first to do hard work. As Xenophon pointed out to his reluctant officer colleagues, "you get more pay and more respect than other soldiers do". Much that is written about millitary leadershtp is of great relevance to the mental health services. Keegan (1988), for instance, lists five imperattves for leaders.

(a) The imperative of kinship - the ability to create a bond of understanding between themselves and their team.

(b) The imperattue of prescription - the ability to talk directly to a team, to raise their spirits in times of trouble. inspire them in a crisis and thank them for success.

(c) The imperattue of sanction - the ability to praise and to criticise constructively.

(d) The imperattue of action - to be known to be willing to make decisions and to take necessary action.

Finally and perhaps most importantly,

(e) The tmperattue of example - to be known for conspicuous participation in the problems confronting others. A leader whether of an army, a multidisciplinary team or a clinical directorate must share the problems of the team. The consequences of being a 'chateau general' remote from the action were only too clear in the Furst World War (Dixon, 1976/1994). Yet they were repeated by some medical superintendents; clinical directors must avoid making similar mistakes.

\section{The sources of authority}

Leaders have authortty and it has been argued that three sources of authority exdst:

(a) the authority of posttion - job title, (Dr or Professor), or appointment -(consultant, clinical director)

(b) the authortty of knowledge-technical, professional

(c) the authority of personal attributes style of workdng, way of relating to colleagues (Adair, 1987).

If doctors are wary of leadership perhaps they are over-influenced by memories of 'leaders' relying solely on the authority of position - in the case of older psychiatrists 
or medical superintendents of the less capable sort. Or for younger psychiatrists, clinical directors appointed without proper thought about their sources of authority. Psychiatrists who wish to establish themselves as leaders whether of a multidisciplinary team, a clinical directorate or at a higher level must gain these roles not on the authority of position alone. It is no longer acceptable for a psychiatrist to say "I am a consultant psychiatrist, therefore I must be the leader of the multidisciplinary team," or for a clinical director to be appointed without consideration of his/her personal as opposed to technical abilities. For the future leadership should be determined not by position and technical knowledge alone but also by wider knowledge and by personal qualities.

These necessary personal characteristics have neatly been summed up by Adair (1983).

(a) Initiative - the ability to start action and get the group moving.

(b) Perseverance - the ability to help the team to stick to tasks even under difficulties.

(c) Integrity - to create a climate of trust in the group.

(d) Tact-consideration in dealing with team members.

(e) Compassion - in dealing with individuals' work and home problems.

(f) Humour - essential on those black days all teams face.

(g) Humility - also is very necessary. But not to excess; as Winston Churchill once said to Violet Bonham-Carter: "We are all worms but I do believe I am a glowworm."

\section{Training in leadership}

There is currently a much greater interest in ideas of leadership at least outside medicine. Many organisations give leadership training even though it may sometimes have a more politically correct name.

The position of public airline pilots is particularly interesting. They, like psychiatrists, work as part of a multdisciplinary team, at times under intense pressure. To them, re-accreditation about which we worry so much is nothing new. Renewal of licence is required every six monthsl Audit, with which doctors are still coming to terms, also is not new to aircrew and audit results show the similarities between aviation disasters and mental health service disasters; the most common cause of aviation accidents is fallure of the cockpit crew to work to common goals and to communicate effectively under stress.

A consequence of these audit findings is that it is now mandatory for all cockpit crew to undergo 'crew resource management' training and for the commander in addition to have training to make sure he is capable of making effective use of his team's specialised skdlls. The extent to which this training in team working can pay off is shown by the landing of a DC10 at Salt Lake City in 1989 after engine fallure had put all flying controls out of operation. Nobody knew you could fly, let alone land, a plane with no flying controls yet what seemed a certain total loss was turned round when the commander and his crew by reasoning, experiment and close co-operation discovered how to fly and land the aircraft on engine power alone.

There is no doubt that audit of accidents and training and relicensing of crew have greatly contributed both to airline safety and to public confidence in air-travel. There are lessons here for doctors in the mental health service and for the focusing of higher and continuing medical education.

\section{Training in medical leadership}

Since leadership in mental health care is unavoldable doctors have a responsibility to try to ensure that it is of high quality. Leadership by doctors is again a topic for debate stimulated not least by Smith (1992) 93) in his Trevor Lloyd Hughes memorial lecture and by the Chief Medical Officer (Smith, 1994). Smith has pointed out that "Doctors have problems with leadership." Perhaps, in his view, because "they have been used to working as individuals, in one to one relationships with patients. They guard their independence jealously, and they value autonomy highly. Yet leadership is about working with others."

At present leadership training, if considered at all in psychiatry, is thought of only for the select few 'high-fliers' (and there is certainly a need for that) rather than as an integral part of training for all psychiatrists. Many think that leadership skdlls can be picked up by some process of informal osmosis. But as Henry Ford said, "By the time man is ready to 
graduate from the Untversity of Experience, he is too old to work". And that shrewd observer George Bernard Shaw recalled the very high fees payable at that untversity.

Plato understood this. Training for leadership had to start when future leaders were young: "We must not let ourselves be persuaded that a man can learn many things as he grows old. Youth is the time for hard work of all sorts." (Plato, translation 1941).

If leadershtp is expected from doctors what preparation do they have for this difficult role? The Education Committee of the General Medical Council $(1987,1993)$ in a paper on Recommendations on the Training of Specialists, says inter alia that:

"Education and training for specialists should not only include acquisition of the technical knowiedge and skdlis of a particular spectality or branch but also development of (certain) attributes..."

These 'Attributes of the Independent Practitioner' include:

"Mastery of the skdlls required to work with a team and, where approprlate, assume the responsiblitiles of team leader." Including "the ability to lead, guide and co-ordinate the work of others."

How does the Royal College of Psychiatrists aim to develop this attribute among trainees and enhance it in consultants through continuing medical education? The most recent (1990) edition of the Joint Committee on Higher Psychiatric Training (JCHPT) handbook, in its section on Aims and Objectives of Trainings speaks only of developing skills in "communication with patients, relattves, colleagues and members of other disciplines." The section on "Some Contemporary Issues' says that "opportunity must be found for training in the basic theory and practice of management." This is picked up as the last (and hence by implication the least important) item in the training requirements for each speciality. These are admirable educational objectives but they do not mention leadership.

The situation is perhaps changing and the College's initiattres in this area are very welcome. The decision to work with the Health Advisory Service and the Institute of Health Service Management to develop a learning set on strategic leadership, the proposed revision of the JCHPT Handbook, the decision to examine the College's educational strategy and to reconsider the
College's statement on the role of the consultant are all opportunities to consider leadership and other important issues (Muijen, 1993).

\section{The poychiatriat as a 'personal doctor'}

Any successes that doctors have had in the past in shaping the future development of the mental health service have come from an awareness of the needs and wishes of mentally ill people and by promoting change to meet those needs.

In an earlier paper I examined the central role of the consultant in the NHS as a patient's personal doctor... "at the highest medical level in whom (the patient) can place his trust and confide the most intimate of his aspirations fears and secrets in the assurance of confidentiality.... The advantages of this personal doctor service, where responsibility is accepted by and anchored in a named individual rather than 'a service' or 'a team' are clear and are certainly appreciated by our patients" (Reed, 1991).

Despite this appreciation, professionals including psychiatrists are probably less trusted now than they have been in the past. One recent survey, admittedly scientifically flawed, showed that only 12\% of in-patients considered their psychiatrist the person who helped them the most, well behind nurses (32\%) and level-pegging with social workers. Worse still psychiatrists headed the list of those who helped least - at 21\% well ahead of social workers at $18 \%$. Only $55 \%$ of patients found their psychiatrist helpful or very helpful and less than half found them easy to talk to (Rogers et al, 1993).

The role of personal physician imposes responsibilities on a consultant who already has many onerous tasks but perhaps one more should be added to the list - the responsibility to develop jointly with patients and their families, a vision for the mental health services for the next century. Such an alliance could be one of great power and influence.

\section{A bright future}

A recently retired colleague in a farewell lecture could see no cause for optimism about the future for the mental health services. Perhaps this was just another manifestation of an oddity that Enoch Powell 
first noted, that the NHS "presents what must be the unique spectacle of an undertaking that is run down by everyone engaged in it" (Powell, 1975).

There are, on the contrary, many reasons to be very optimistic. Mental health has never occupied a higher profile nationally than it does now as one of the five priority areas (Department of Health, 1992b) targeted for health gain in The Health of the Natton A Secretary of State has never before said that her Chief Executtve will personally take responsibllity for ensuring that all health authorities deliver on policy commitments and meet clear targets for improvements in the mental health service where these are necessary (Department of Health, 1994).

To build on this central determination to forge a better service people are needed willing to undertake the exacting role of leaders in taking the service forward - and it is to be hoped that many of these leaders will be psychiatrists. But to achieve this highly desirable goal psychiatrists must develop the skills needed to play their proper role in the future effective leadership of the mental health service.

\section{References}

ADAR, J. (1983) Effecthe Leadershtp, Aldershot: Gower. BOAPD OF CONTROL (1919) The Fyth Annual Report of the Boand of Control (for the year 1918). pp1-2. HMSO (1919)

DEPARMMENT OF HEALTH (1992a) Report of the Committee of Inquitry tnto Complatints about Ashworth Hospttal. Cmnd 2028-1. London: HMSO.

- (1992b) The Health of the Nation: a strategy for health in England. London: HMS Cmnd 1986

- (1994) 'Clunis case shows the need for tighter community care'. Press Release 94-102. 24 February 1994.

DEPARTMENT OF HEAlTh \& SOcinl SECURTY (1975) Better Services for the Mentally Im. London: HMSO. Cmnd 3975.

- (1972) Report of the Committee of Inquiry tito Whittingham Hospttal,(Cmnd 4861) London: HMSO.

- (1969) Report of the Committee of Inquitry tinto Allegations of Ill-treatment of Pattents and other trregulartiles at the Ely Hospital, Cardiff. Cmnd 3975. London: HMSO.

DEPARMMENT OF HEALTH \& SOcinl SERvices (1974) Report of the Committee of Inquitry trito South Ockendon Hospittal. London: HMSO.

DEPARTMENT OF SOCINL SERVICEs (1971) Report of the Farletgh Hospttal Committee of Inquitry. Cmnd 4557. London HMSO.

Dxon, N. (1976-1994) The Psychology of Maltary Incompetence. London: Pimilico.

General Mredical CoUncil (1987) Education Committee Recommendations on the Tratinting of Spectalists. London: GMC.
- (1993) Tomorrow's Doctors: Recommendations on Undergraduate Medical Bducation. London: GMC.

GoODE, T. S. (1930) The history and progress of Littlemore Hospital. Joumal of Mental Sclence, 78, 602-621.

- (1954) The unlocked door. Lancet, 2, 1130.

Kmban. J. (1988) The Mask of Command. London: Penguin. LAverT (1954) The unlocleed door. Lancet, 2, 954-955.

- (1954) Freedom in mental hoopitals. Lancet, 2, 964-966.

Mnstow A. H. (1965) Eupsychian Management: a Joumal Irwin.

Mnnstry OF Hralth (1960) On the State of the Public Health for the Year 1959. (Cmnd 1207). London: HMSO.

Moscovici. S. (1986) Epilogue. In Changtng Conceptions of Leadershtp (eds. Graumann, S. F. \& Moscovid, S.) Berilin: Springer.

MUrJE, M. (1993) The consultant poychiatrist and community care. Psychiatric Bulletin, 17, 513-516.

PuATo The Republic (trans. Cornford. F. M. (1941) Oxford Untveratty Press.

Powrul. THE Richt HON J. ENock (1961) Mental hospitals for the future. In Emerging Patterns for the Mental Health Services and the Public. Proceedings of a conference held at Church House, Westminster, 9-10 March 1961. London: National Association for Mental Health.

- (1975) Medictne and Polttics London: Pitman Medical.

RuMON, S. (1985) Psychiatry in Brttain: meaning and policy. Beckenham: Croom Helm.

Rresod. J. (1991) The future for poychiatry. Psychidatic Bullettr, 80, 396-402.

Rrrctir., J. H. DiCK, D. \& LnGrin, R. (1994) The Report of the Inquitry tits the Care and Treatment of Christopher Clunis. London: HMSO.

Rocmes, A. PILORM. D. \& LACEY, R. (1993) Expertencting Psychiatry: users' Views of Services. Macmillan/MIND.

RoYal Courso: Or PsYchintrists (1992) The Mental Health of the Nation. London: RCP.

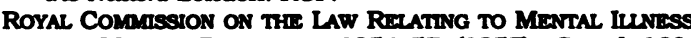
AND Mental Denciency 1954-57 (1957). Cmnd 169. London: HMSO

SFCRETARY OF STATE FOR SOCIAL SERVICES (1977) Addrese to All-Party Parilamentary Mental Health Group. In Organisation and Management Problems of Mental Illness Hospitals: report of a working group. London: Department of Health and Soclal Security.

Sns, A. (1989) What is the role of the consultant in the community Psychiatric Bulletin, 18, 285-287.

- \& Snis, D. (1993) Top teams. Health Service Journal, 24 June 1993, pp $28-30$.

SMrth. J. (1994) A rebulse from the Chief Medical Oficer Brtilsh Medical Journal, S08, 1322.

Sumi. R. (1992/93) Doctors and leadership: ofl and water? Trevor Lloyd Hughes Memorial Lecture, Ltverpool Medical Institution Transactions and Report.

South Divon Hiniticara (1994) Report of the review of the Mental Health Services of South Devon Healthcare Trust STEWART, R. (1989) Leading in the NHS: a practical guide. London: Macmillan.

WHrre. E. (1991) Thind Qutnquennial Survey of Community Psychiatric Nurses. Untveraity of Manchester.

XENOPHON The Perstan Expedition (trans. Warner, R) (1949) Harmondoworth: Penguin.

John Reed, CB. Spectal Adviser in Forensic Psychiatry, Department of Health, Wellington House, 133-155 Waterloo Road, London SE1 8UG 